\title{
Correction to: The Synergistic Effect of Descriptive and Injunctive Norm Perceptions on Counterproductive Work Behaviors
}

\author{
Ryan P. Jacobson ${ }^{1}$ - Lisa A. Marchiondo ${ }^{1} \cdot$ Kathryn J. L. Jacobson ${ }^{1}$. Jacqueline N. Hood ${ }^{1}$
}

Published online: 23 August 2018

(c) Springer Nature B.V. 2018

Correction to: Journal of Business Ethics

https://doi.org/10.1007/s10551-018-3968-1

The name of the third author was incomplete in the initial online publication. The original article has been corrected.

The original article can be found online at https://doi.org/10.1007/ s10551-018-3968-1.

Ryan P. Jacobson rjacobson@unm.edu

Lisa A. Marchiondo marchiondo@unm.edu

Kathryn J. L. Jacobson

kjacobson@unm.edu

Jacqueline N. Hood

jnhood@unm.edu

1 Anderson School of Management, University of New Mexico, MSC05 3090, 1, Albuquerque, NM 87131-0001, USA 